\title{
ANALYSIS OF ENERGY-EFFICIENT HOUSE LAYOUT DESIGN IN TROPICAL CLIMATE
}

\author{
Aisyah Zakiah \\ Department of Architecture, Universitas Islam Indonesia, Yogyakarta, INDONESIA \\ Email: aisyah.zakiah@uii.ac.id
}

\begin{abstract}
Energy-efficient residential provision is an essential concern for the present and future city development. Currently, the residential buildings contribute approximately $37.5 \%$ to significant energy consumption and carbon emissions, which mainly used for cooling. This research aims to study the house layout arrangement to minimise cooling loads and further reduce energy consumption. Energy efficiency analysis is performed by comparing the cooling load and total energy consumption from variations of the hypothetical design of detached or semi-detached housing layouts commonly built in Indonesia. The calculation of cooling loads and energy consumption is performed by simulation in Energy Plus 8.4 with Jakarta weather data. The results show that the arrangement of the house layout may reduce the cooling load up to $24 \%$. The total conditioned wall area that varies due to the variations of house layouts are found to affect the cooling loads.
\end{abstract}

Keywords: Building simulation; cooling load; energy-efficient; house layout.

\section{INTRODUCTION}

According to the Indonesian Ministry of Energy and Mineral Resources-MEMR (2019), the building contributes to $11 \%$ of the global electricity consumption. Moreover, the International Energy Agency notes that the total energy consumption in Indonesia during 26 years gradually increased from $29.48 \mathrm{TWh}$ to $225.91 \mathrm{TWh}$. Accordingly, the use of an air conditioner for room cooling becomes the most prominent energy consumption in the world, and the electricity demands are predicted to rise sharply in 2050 (International Energy Agency, 2018). Based on this predicted future condition, housing should be designed to minimise the use of energy for cooling.

In 2011, the household energy consumption in Indonesia was the second-largest energy consumption after the industry sector, reaching 319.280.000 SBM or approximately $37.5 \%$ of final total energy consumption (Indonesian Ministry of Energy and Mineral Resources, 2019). A further survey conducted by MEMR results in the air conditioning equipment using $26.5 \%$ of total energy consumption in the household. In line with this, the use of electrical energy in many countries with a hot humid climate is mostly for air conditioning usage (Chua, Chou, Yang, \& Yan, 2013). The occupant's preference to use air conditioning in Tropical countries for cooling is unavoidable due to the high overheating hours reach about $81 \%$ (Harkous, 2018).

The use of air conditioning is not the only option for room cooling for residential buildings. However, when the use of air conditioning is inevitable, minimising the cooling load will significantly contribute to the reduction of energy consumption for cooling in the household.

Numerous researches have been conducted and concluded that the energy saving of houses is influenced by the local climate and building materials composed (Koroneos \& Kottas, 2007) (Praznik et al., 2013). The previous study also showed that the type of windows significantly influences the indoor air temperature in a humid tropical city (Ayanlade et al., 2019). Moreover, another study has been conducted to include a green roof and an insulation system to reduce the energy consumption of air-conditioning (Jim, 2014).

While other factors may also influence the cooling load and further reduce energy consumption, this research mainly focuses on the arrangement of house layout. This research aims to study house layout arrangements in minimising the cooling loads and reducing the energy consumption for cooling.

The factor affecting the energy consumption for cooling is the rate of cooling loads. This rate shows that the total amount of heat must be removed from the spaces to keep the air temperature in the range of the constant thermal set. Building cooling load is generally affected by 1) external loads, which transfer heat through the building envelope, i.e., walls, roofs, floor and windows, and 2) internal loads, i.e., people, light and equipment (Mechanical Engineering, 2017).

On the other hand, the behavioural issues significantly influence household energy consumption for cooling, exemplified by choice of how often and where the air-conditioning is used (Yun \& Steemers, 
2011). Occupant behaviour such as the habit of opening the windows is also found to affect the use of energy to operate air conditioning $(\mathrm{Yu}, \mathrm{Du}, \& \mathrm{Pan}$, 2019). Split types of AC are commonly installed for homes, and the residents are expected to consistently close all windows and doors when the $\mathrm{AC}$ is turned on.

Landed house is still the most preferred residential property in Indonesia. It is usually in the shape of a detached house or a semi-detached house, which is practically preferred in the housing area. The semidetached house generally has one side or two sides attached to other buildings with mirroring façade.

\section{METHOD AND MATERIAL}

The simulation method is preferred in this research due to maintaining controlled variables such as room volume, materials and occupant behaviour, which is less likely to be controlled in the experimental method. Occupant behaviour, especially in a residential building, is varied and complicated, thus reduces the accuracy to gain total energy usage for air conditioning from post-occupation data $(\mathrm{Yu}, \mathrm{Du}, \&$ Pan, 2019). The result from the simulation method is also identical with the result from factual data, which commonly has more limitations due to weather and consistency of the measurement process (Jesha \& Iqbal, 2015). Moreover, using Energy Plus to model a detailed control system as an energy simulation tool will enhance accuracy by $14 \%$ in a residential building (Yu, Du, \& Pan, 2019).

\section{Local Climate}

The simulation is done using the Jakarta weather file (.epw) format. The input location data was set in latitude -6.204 , longitude 106.821, time zone GMT +7 and elevation 10 meters. The weather file consists of several data, including location, temperature, humidity, radiation, wind and precipitation.

\section{Building Layout and Orientation}

The models set for simulation are single-storey buildings with a floor area of approximately 60 square meters in total. Each house type is composed of 5 rooms including; 2 Bedrooms (BR1 and BR2), a Living Room (LR), a Kitchen (K) and a Bathroom (BT). BR1 is located in the South portion of the house and the BR2 situated in the North portion of the house. Floor to ceiling ratio is set at 3.5 meters. The models have the main orientation to the north and south plus layout variations with one or two sides attached to other buildings and set as adiabatic.

The simulation runs mainly two types of house layouts with vertical or horizontal arrangements. Each layout type has four variations regarding detached house or semi-detached house type with one side or both sides attached, commonly built in Indonesia. Variation 1: vertical layout, left side attached to other building. Variation 2: vertical layout, the right side is attached to other building. Variation 3: vertical layout both for the left and right sides attached to other buildings. Variation 4; horizontal layout, left side attached to the other building. Variation 5: horizontal layout, the right side is attached to other building. Variation 6: horizontal layout- both left and right sides are attached to other buildings. The simulation is also accompanied by base design, which stands as a detached house.
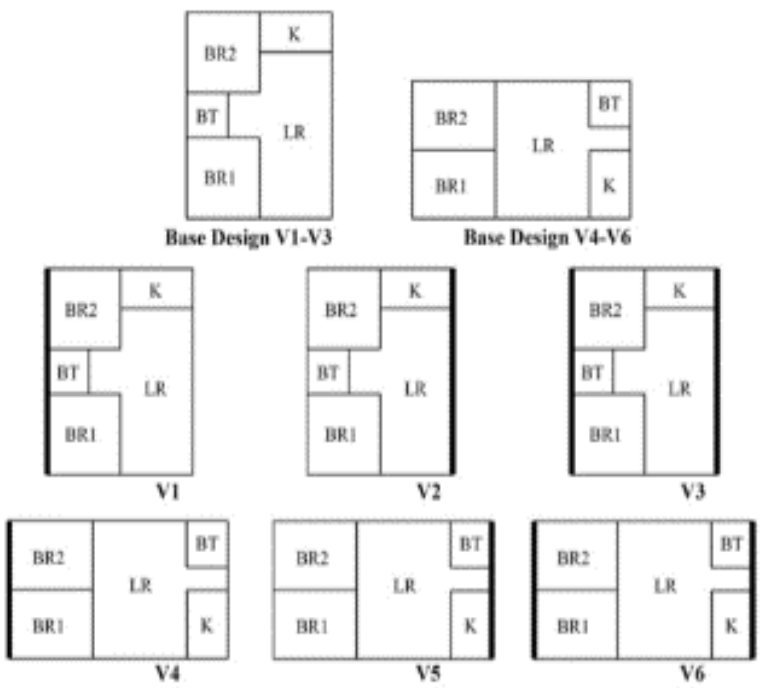

Figure 1. Layout Variation of Models (adiabatic wall in bold)

\section{Modelling}

All variations are modelled using Legacy Open Studio in the SketchUp 3D modelling software. Each room is defined as an individual thermal zone with window openings and shading attached. The zone between the roof and ceiling is modelled as a separated zone connected to the occupied zone below.

All building surfaces are categorised into an exterior wall, interior wall, interior floor, interior ceiling and exterior roof. The fenestration is classified as an exterior window. The exterior walls attached to other buildings in the semi-detached houses model are set as adiabatic with no exposure to the sun and wind (Figure 4 \& 5). 


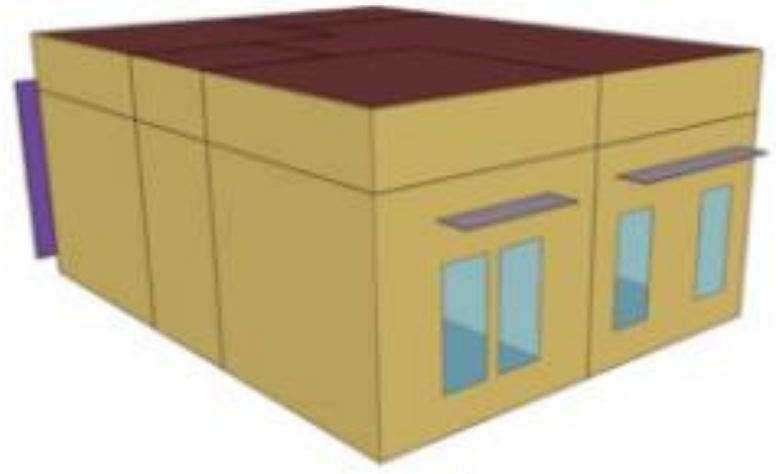

Figure 2. Typical model for Variations 1 to 3 (vertical layout arrangement)

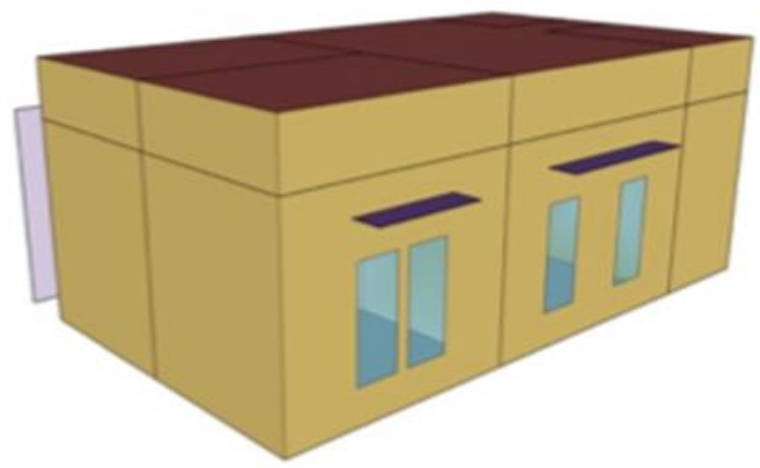

Figure 3. Typical model for Variations 4 to 6 (horizontal layout arrangement)

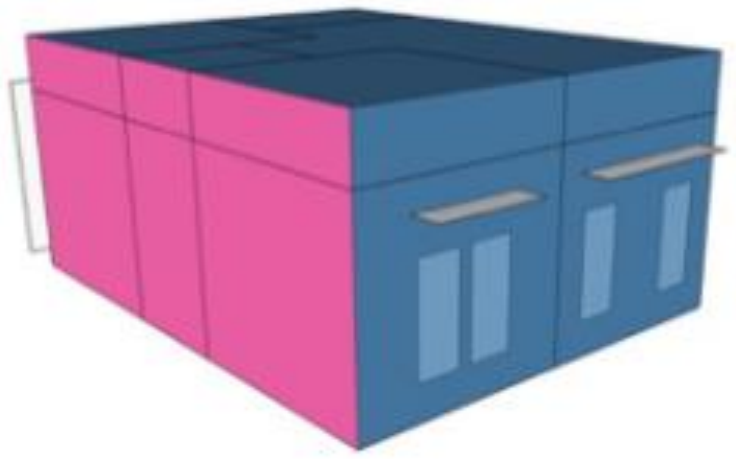

Figure 4. Typical model for Variations 1 to 3 with wall attached to other buildings set as adiabatic (in violet)

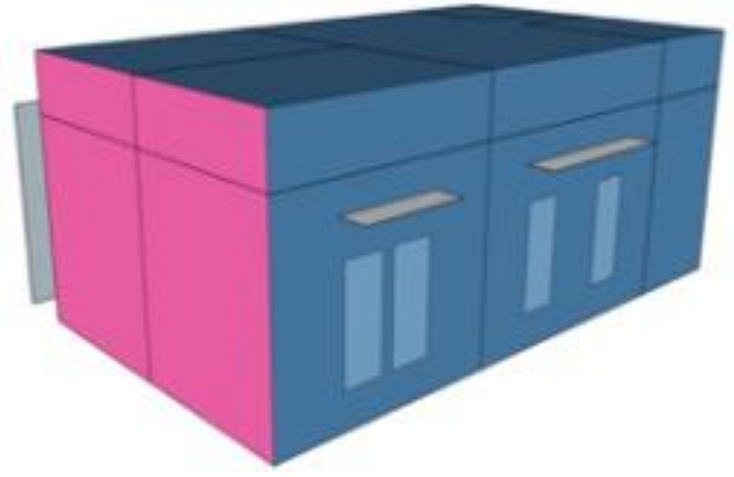

Figure 5. Typical model for Variations 3 to 6 with wall attached to other buildings set as adiabatic (in violet)

Tabel 1. Construction

\begin{tabular}{llllll}
\hline Name & Exterior/Interior Wall & Interior Floor & Interior Ceiling & Exterior Roof & Exterior Window \\
\hline Outside Layer & Plaster-Wall & Cement Sand & Gypsum & Concrete Roof & Clear 3mm \\
& & Plasterboard & Tile & \\
Layer 2 & $\begin{array}{l}\text { Lightweight Concrete } \\
\text { 100mm }\end{array}$ & $\begin{array}{l}\text { Ceramic } \\
\text { Layer 3 }\end{array}$ & & & \\
\hline
\end{tabular}

Tabel 2. Material

\begin{tabular}{|c|c|c|c|c|c|c|c|}
\hline \multirow[b]{2}{*}{ Specification } & \multicolumn{5}{|c|}{ Opaque Materials } & \multirow[b]{2}{*}{ Specification } & \multirow{2}{*}{$\begin{array}{c}\text { Glass } \\
\text { Material } \\
\text { Clear Glass } \\
\text { 3mm } \\
\end{array}$} \\
\hline & $\begin{array}{c}\text { Lightweight } \\
\text { Concrete } \\
100 \mathrm{~mm} \\
\end{array}$ & $\begin{array}{c}\text { Plaster } \\
\text { Wall }\end{array}$ & Ceramic & $\begin{array}{c}\text { Gypsum } \\
\text { Plasterboard }\end{array}$ & $\begin{array}{l}\text { Concrete } \\
\text { Roof Tile }\end{array}$ & & \\
\hline Thickness (m) & 0.1 & 0.015 & 0.003 & 0.015 & 0.01 & Thickness (m) & 0.003 \\
\hline $\begin{array}{l}\text { Conductivity } \\
(\mathrm{W} / \mathrm{m}-\mathrm{K})\end{array}$ & 0.53 & 0.16 & 1.3 & 0.25 & 1.13 & $\begin{array}{l}\text { Solar } \\
\text { Transmittance }\end{array}$ & 0.837 \\
\hline Density (kg/m) & 1280 & 600 & 2300 & 900 & 2000 & $\begin{array}{l}\text { Front Side Solar } \\
\text { Reflectance }\end{array}$ & 0.075 \\
\hline $\begin{array}{l}\text { Specific Heat } \\
(\mathrm{J} / \mathrm{kg}-\mathrm{K})\end{array}$ & 840 & 1000 & 840 & 1000 & 1000 & $\begin{array}{l}\text { Back Side Solar } \\
\text { Reflectance }\end{array}$ & 0.075 \\
\hline $\begin{array}{l}\text { Thermal } \\
\text { Absorptance }\end{array}$ & 0.9 & 0.9 & 0.9 & 0.9 & 0.9 & $\begin{array}{l}\text { Visible } \\
\text { Transmittance }\end{array}$ & 0.898 \\
\hline Solar Absorptance & 0.5 & 0.5 & 0.4 & 0.5 & 0.6 & $\begin{array}{l}\text { Front Side } \\
\text { Visible } \\
\text { Reflectance }\end{array}$ & 0.081 \\
\hline $\begin{array}{l}\text { Visible } \\
\text { Absorptance }\end{array}$ & 0.5 & 0.5 & 0.4 & 0.5 & 0.6 & $\begin{array}{l}\text { Back Side } \\
\text { Visible } \\
\text { Reflectance }\end{array}$ & 0.081 \\
\hline
\end{tabular}




\section{Modelling Assumption}

The cooling load and energy consumption simulation are done annually from January $1^{\text {st }}$ to December $31^{\text {st }}$. The construction components are set for both the building envelope and interior material. All constructions are defined in every surface and fenestration in layers (Table 1). In this simulation, materials are set as a controlled variable (Table 2); the exterior wall set as lightweight concrete $100 \mathrm{~mm}$ that has U-value $1,039 \mathrm{~W} / \mathrm{m} 2 \mathrm{~K}$ and the window set as Clear glass $3 \mathrm{~mm}$.

Tabel 3. Occupancy

\begin{tabular}{|c|c|c|c|}
\hline \multirow{2}{*}{ Field } & \multirow{2}{*}{ Unit } & \multicolumn{2}{|c|}{ Zone } \\
\hline & & $\mathbf{B R}$ & LR \\
\hline Number of & & People & People \\
\hline \multicolumn{4}{|l|}{ People } \\
\hline \multicolumn{4}{|l|}{ Calculation } \\
\hline \multicolumn{4}{|l|}{ Method } \\
\hline Number of & Person & 2 & 4 \\
\hline \multicolumn{4}{|l|}{ People } \\
\hline Fraction Radiant & & 0.3 & 0.3 \\
\hline Sensible Heat & & Autocalculate & Autocalculate \\
\hline \multicolumn{4}{|l|}{ Fraction } \\
\hline $\mathrm{CO} 2$ Generation & $\mathrm{m}^{3} / \mathrm{s}-\mathrm{W}$ & 0.0000000382 & 0.0000000382 \\
\hline \multicolumn{4}{|c|}{ Rate } \\
\hline Mean Radiant & & Zone & Zone \\
\hline Temperature & & Averaged & Averaged \\
\hline \multicolumn{4}{|l|}{ Calculation Type } \\
\hline Clothing Schedule & & ID Clothes & ID Clothes \\
\hline Name $(*$ & & $(0.5)$ & $(0.5)$ \\
\hline
\end{tabular}

Tabel 4. Lighting

\begin{tabular}{lcc}
\hline Field & Lighting Power & Unit \\
\hline Bedroom & 18 & $\mathrm{~W}$ \\
Living room & 18 & $\mathrm{~W}$ \\
Kitchen & 6 & $\mathrm{~W}$ \\
Bathroom & 4 & $\mathrm{~W}$ \\
\hline
\end{tabular}

Tabel 5. Equipment

\begin{tabular}{ll}
\hline Name & LR LED TV \\
\hline Design Level Calculation Method & Equipment Level \\
Design Level & 100 \\
Fraction Radiant & 0.2 \\
End-Use Subcategory & LED TV \\
\hline
\end{tabular}

\section{Simulation Setting}

Schedule of internal loads consist of occupancy, lighting and equipment, which can be obtained from a standard, literature and empirical concept ( $\mathrm{Yu}, \mathrm{Du} \&$ Pan, 2019). The amount of heat load generated and the electrical load required by each component depends on the input power and the operational schedule. The internal loads are setting for the conditioned zone; Bedroom and Living room are shown in Table 3, 4, and 5.

For the occupancy schedule, all occupants are defined as working adults, which during the weekdays daytime are expected to leave the house for work. The regular working hours are from 8:00 18:00 (Yu, Du, \& Pan, 2019); based on this assumption, the schedule for house occupancy can be seen in Figure 6 and 7.

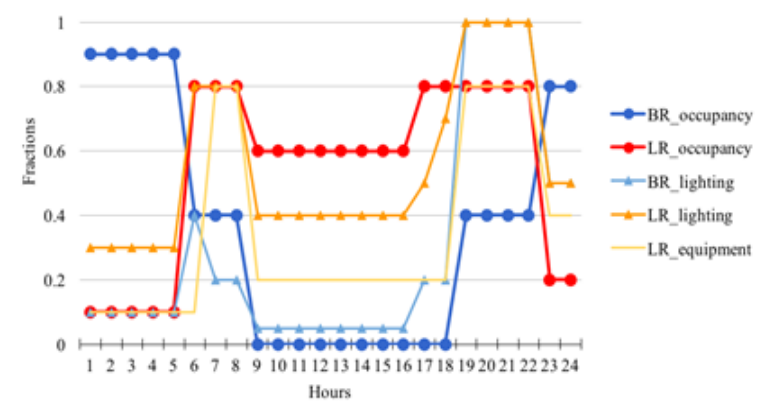

Figure 6. Internal Load Schedule Weekdays

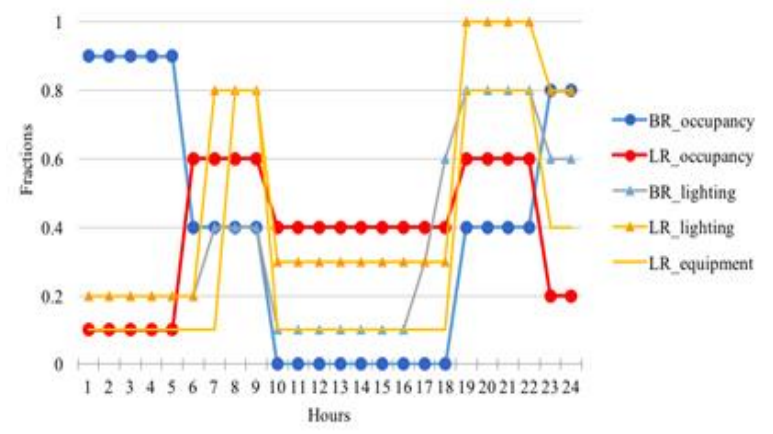

Figure 7. Internal Load Schedule Weekends and Holidays

\section{Hvac Setting}

In this simulation, only the Bedroom and Living room are set as a conditioned zone with a constant set point at 25 degrees Celsius. All conditioned zones are equipped with split type air conditioning Daikin $1 / 2$ HP for Bedroom with 5100 BTU 380 Watt and COP 4.45 and Daikin 1 HP for the Living room with 8500 BTU and COP 3.67.

Maintaining positive pressure in a conditioned room is difficult due to low mechanical ventilation rate or poor building airtightness (Shi \& Li, 2018), which commonly happens in the doorpost (Gonçalves, Costa, \& Lopes, 2019), and occupant behaviour (Yun \& Steemers, 2011). Therefore, the infiltration rate in this simulation is set to 0.6 air changes per hour. 
Tabel 6. Infiltration

\begin{tabular}{lll}
\hline Name & Bedroom & Living Room \\
\hline $\begin{array}{l}\text { Design Flow Rate } \\
\text { Calculation Method }\end{array}$ & Air Changes/ & Air Changes/ \\
$\begin{array}{l}\text { Air Changes per } \\
\text { Hour }\end{array}$ & 0.6 & Hour \\
$\begin{array}{l}\text { Velocity Term } \\
\text { Coefficient }\end{array}$ & 0.2237 & 0.6 \\
\hline
\end{tabular}

Tabel 7. HVAC Parameter Setting

\begin{tabular}{lll}
\hline Name & Bedroom & Living Room \\
\hline $\begin{array}{l}\text { Gross Rated Total } \\
\text { Cooling Capacity } \\
\text { Gross Rated Cooling }\end{array}$ & 5100 & 8500 \\
$\begin{array}{l}\text { COP } \\
\text { Minimum Outdoor } \\
\text { Temperature in Cool- }\end{array}$ & 6 & 3.67 \\
$\begin{array}{l}\text { ing Mode } \\
\text { Maximum Outdoor } \\
\text { Temperature in } \\
\text { Cooling Mode }\end{array}$ & 43 & 6 \\
\hline
\end{tabular}

\section{RESULT AND DISCUSSION}

The simulation focused on calculating the conditioned zone, which includes the Bedrooms and Living room. Exclude the kitchen and bathroom that are not commonly conditioned. The parameter of the conditioned zone in each house layout variations remains identical, as detailed below.

Tabel 8. Conditioned Zone Detail

\begin{tabular}{llll}
\hline \multirow{2}{*}{ Parameter } & \multicolumn{3}{c}{ Conditioned Zone } \\
\cline { 2 - 4 } & BR 1 & BR 2 & LR \\
\hline Area (m2) & 12.25 & 12.25 & 55 \\
Volume (m3) & 42.88 & 42.88 & 192.5 \\
Windows Glass Area (m2) & 2.52 & 2.52 & 2.52 \\
\hline
\end{tabular}

\section{Cooling Load}

The simulation generally produces the data of cooling load need to maintain the temperature at 25 degrees Celsius. Figure 8 shows that the reduction of wall area exposed to the outdoor condition of the conditioned zone due to changes in building layout decreases the cooling load. The size and orientation of the exterior surface prooved to affect the energy efficiency of the building (Wang, Rivard, \& Zmeureanu, 2006).

The change in the total conditioned wall area influences the total cooling load. It shows in V3, which has both sides of the house attached to other buildings, thus reducing the area of exterior surface affected by outdoor conditions. The reduction of the conditioned wall in V3, approximately $57 \%$ of the base design, reduces the cooling load by $24 \%$. The minimum change in cooling load reduction may be caused by the constant volume of the conditioned zone. The wall area and volume of the conditioned zone are associated with cooling and energy consumption (Bavaresco \& Ghisi, 2018).

Generally, the house design with vertical layout arrangement easily to get cutback in cooling load by reducing the total conditioned wall area. On the other hand, the horizontal layout has more wall areas exposed to the external condition, which makes it harder to reduce the cooling load. The maximum reduction of the conditioned wall area in the variations of the horizontal layout is less than $25 \%$, where approximately only half of the wall area may reduce in a vertical layout.

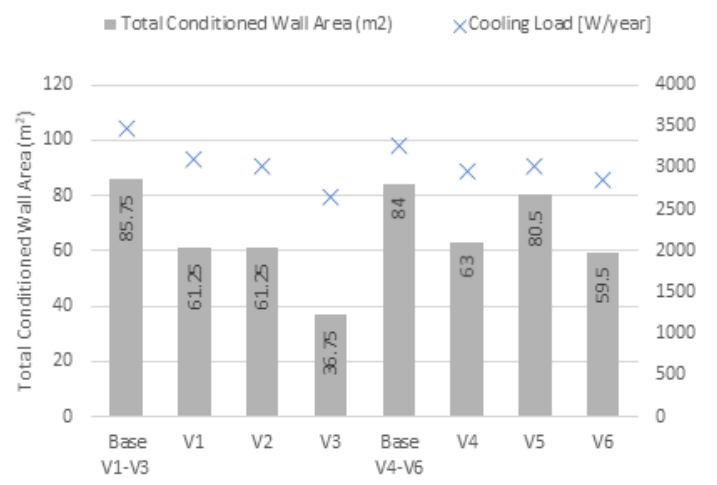

Figure 8. Total Cooling Load and Total Conditioned Wall Area in All Variation of House Layout

Tabel 9. Annual Cooling Load

\begin{tabular}{lcc}
\hline Model & $\begin{array}{c}\text { Total Conditioned } \\
\text { Wall Area }(\mathbf{m})\end{array}$ & $\begin{array}{c}\text { Cooling Load } \\
\text { [W/year] }\end{array}$ \\
\hline Base V1-V3 & 85.75 & 3475.98 \\
V1 & 61.25 & 3111.4 \\
V2 & 61.25 & 3013.52 \\
V3 & 36.75 & 2649.25 \\
Base V4-V6 & 84 & 3259.81 \\
V4 & 63 & 2956.34 \\
V5 & 80.5 & 3013.52 \\
V6 & 59.5 & 2859.45 \\
\hline
\end{tabular}

Figure 9 shows the total conditioned wall area per conditioned zone. In V3, BR 1, BR 2 and LR have the same total conditioned wall area; however, the cooling load in LR is far on top, which confirms that the volume of the conditioned zone affecting the cooling load remains high. 
Tabel 10. Annual Cooling Load and Energy Reduction

\begin{tabular}{lcccccc}
\hline Model & $\begin{array}{c}\text { Total } \\
\text { Conditioned } \\
\text { Wall Area [m2] }\end{array}$ & $\begin{array}{c}\text { Cooling } \\
\text { Load } \\
\text { [W/year] }\end{array}$ & $\begin{array}{c}\text { Electricity for } \\
\text { Cooling [kWh] }\end{array}$ & $\begin{array}{c}\text { Conditioned Wall } \\
\text { Area Reduction } \\
\text { from Base Design }\end{array}$ & $\begin{array}{c}\text { Cooling Loads } \\
\text { Reduction from } \\
\text { Base Design }\end{array}$ & $\begin{array}{c}\text { Electricity } \\
\text { Reduction from } \\
\text { Base Design }\end{array}$ \\
\hline Base V1-V3 & 85.75 & 3475.98 & 4787.44 & - & - & - \\
V1 & 61.25 & 3111.4 & 4411.07 & $29 \%$ & $10 \%$ & $8 \%$ \\
V2 & 61.25 & 3013.52 & 4335.84 & $29 \%$ & $13 \%$ & $9 \%$ \\
V3 & 36.75 & 2649.25 & 3940.29 & $57 \%$ & $24 \%$ & $18 \%$ \\
Base V4-V6 & 84 & 3259.81 & 4740.95 & - & - & - \\
V4 & 63 & 2956.34 & 4435.13 & $25 \%$ & $9 \%$ & $6 \%$ \\
V5 & 80.5 & 3013.52 & 4335.84 & $4 \%$ & $8 \%$ & $9 \%$ \\
V6 & 59.5 & 2859.45 & 4305.28 & $29 \%$ & 12 & 9 \\
\hline
\end{tabular}

Total Conditioned Wall Area by Direction and Cooling Load per Conditioned Zone

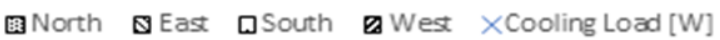

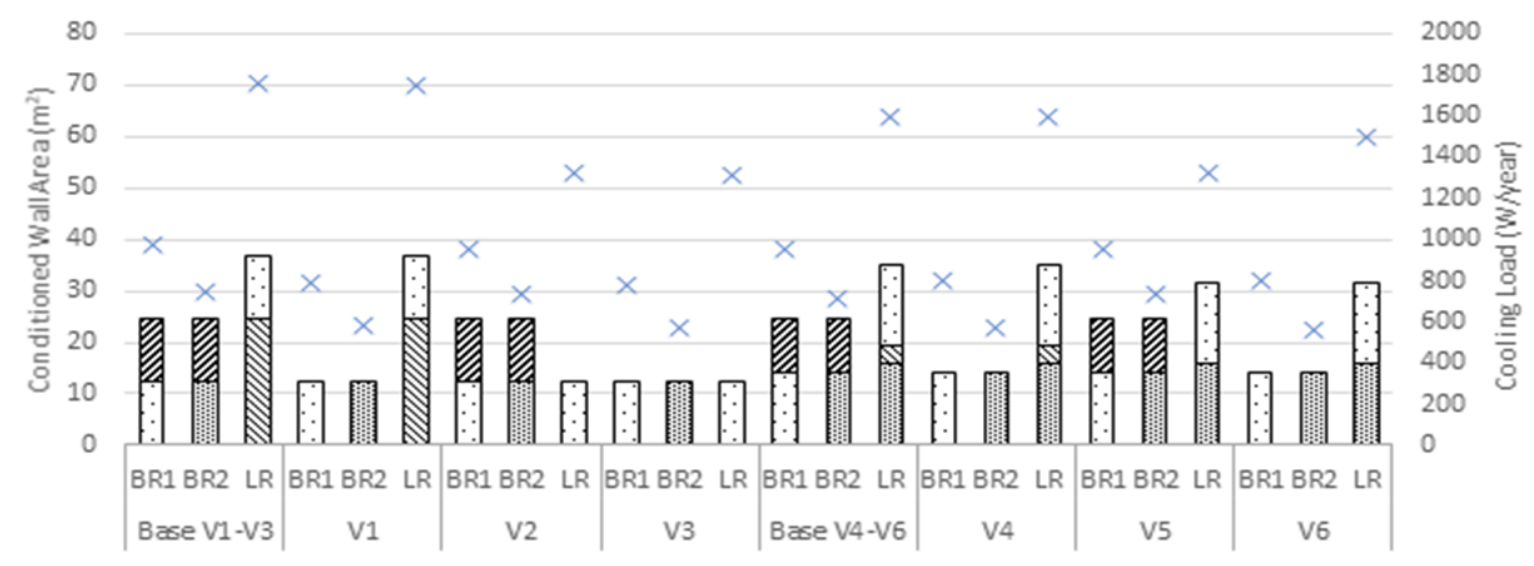

Figure 9. Total Conditioned Wall Area by Direction and Cooling Load per Conditioned Zone

Moreover, in Figure 9, it is clearly observed that the total conditioned wall area matters more for the cooling load as shown in V2 and V3 where the cooling load in LR drops significantly by $24 \%$ from the base design. Inline, the cooling load in BR1 and BR2 in V2 and V3 also decreased slightly from the base design by reducing the total conditioned wall area.

BR1 and BR2 in V1, V3, V4 and V6 have a similar conditioned wall area facing different directions, shown to have a slightly different cooling load. This is not yet confirmed caused by the direction of the wall due to different shading coefficient.

Overall, the lowest total cooling load is shown in V3, a vertical layout with both sides attached to the other building and followed by V2, a vertical layout with one side attached to the other building and V6, a horizontal layout with both sides attached to other buildings. Whereas, a quite noticeable small change of cooling loads is also found in V1, V4 and V5.
These data show that the layout arrangement takes an important role in cooling load reduction.

The layout variations affect the cooling load by reducing the energy needed to cool the space due to the total wall area exposed to the external conditions. The total wall area exposed to the sun increases the external load of a thermal zone. Moreover, as seen in Figure 9, the conditioned zones on the side of the adiabatic wall such as BR1 and BR2 in V1 and in V4, always have lower cooling loads. This indicates that the placement of the conditioned areas surrounded by other rooms can considerably reduce the cooling load.

\section{Energy Consumption for Cooling}

Changes in house layout arrangement have been proven to reduce the electricity usage approximately between 300 to $840 \mathrm{kWh}$ annually. This savings in electricity may cut the annual electricity bill by $1,243,006$ rupiahs per household, assuming the price of electricity is $1,467.28$ rupiahs per $\mathrm{kWh}$. 
Tabel 11. Annual Cooling Load and Energy Reduction

\begin{tabular}{lcccc}
\hline \multicolumn{1}{c}{ Model } & $\begin{array}{c}\text { Cooling Load } \\
\text { [W/year] }\end{array}$ & $\begin{array}{c}\text { Electricity for } \\
\text { Cooling [kWh] }\end{array}$ & $\begin{array}{c}\text { Total Electricity Savings for } \\
\text { Cooling Annually [kWh] }\end{array}$ & $\begin{array}{c}\text { Total Cost Savings for } \\
\text { Cooling Annualy }^{\mathbf{a}} \text { [Rp] }\end{array}$ \\
\hline Base V1-V3 & 3475.98 & 4787.44 & - & - \\
V1 & 3111.40 & 4411.07 & 376.37 & 552,240 \\
V2 & 3013.52 & 4335.84 & 451.60 & 662,624 \\
V3 & 2649.25 & 3940.29 & 847.15 & $1,243,006$ \\
Base V4-V6 & 3259.81 & 4740.95 & - & - \\
V4 & 2956.34 & 4435.13 & 305.82 & 448,724 \\
V5 & 3013.52 & 4335.84 & 405.11 & 594,410 \\
V6 & 2859.45 & 4305.28 & 435.67 & 639,250 \\
\hline
\end{tabular}

${ }^{\mathrm{a}} \mathrm{Rp} 1,467.28$ per $\mathrm{kWh}$

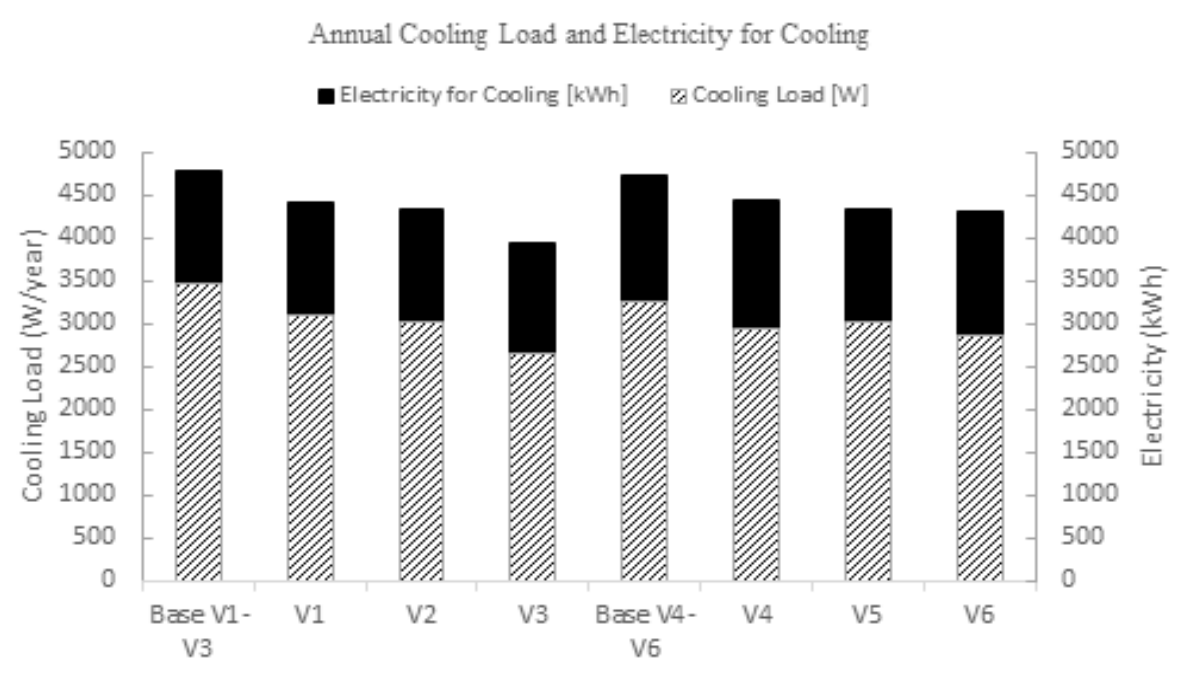

Figure 9. Annual Cooling Load and Electricity for Cooling

Overall, the results show that the arrangement of the house layout may reduce the cooling load between $8 \%-24 \%$, which is significant for reducing the energy consumption similar to green roof installation, but without any additional capital cost. Green roof installation is found to be beneficial in reducing cooling load and energy consumption from $24.37 \%$ $27.79 \%$ on a sunny summer day (Alalouch, Saleh, \& Al-Saadi, 2016).

House layout arrangement is also a promising strategy compared to building orientation strategies, which can only reduce the cooling load below $11 \%$. By changing the orientation of the buildings to the north and south, the cooling load reportedly decreased by approximately $8-11 \%$ (Wong \& Li, 2007). Moreover, the optimal orientation could only reduce the EUI by approximately $4 \%(2.3 \mathrm{kWh} / \mathrm{m} \mathrm{2})$ (Shabunko, Lim, \& Mathew, 2018).

\section{CONCLUSION}

The cooling load significantly increases in line with the total area of the exterior wall exposed to external conditions. The conditioned room in the vertical layout has a lower cooling load than the conditioned room in horizontal layout due to more internal wall being connected to the other rooms. Moreover, the conditioned room attached to the other building in semi-detached housing also has a lower cooling load than the unattached conditioned room. The semi-detached house significantly reduces the cooling load when the conditioned room is placed to the side of the building attached to the other building.

The use of air conditioning may not be better than passive strategies, which requires no operating energy for cooling the house. However, in a condition that the use of mechanical air conditioning is inevitable, minimising the cooling load by optimising the house layout contributes to the reduction of energy consumption in the household significantly.

Although energy simulation is better to calculate energy consumption, the future study on a real scale building experiment is essential for comparison, which should be set identical in size, material, climate condition, lighting schedule, equipment schedule and occupant behaviour. 


\section{REFERENCES}

Alalouch, C., Saleh, M. S., \& Al-Saadi, S. (2016). Energy-Efficient House in the GCC Region. Procedia - Social and Behavioral Sciences, 216, 736-743.

Ayanlade, A., Esho, O. M., Popoola, K. O., Jeje, O. D., \& Orola, B. A. (2019). Thermal condition and heat exposure within buildings: Case study of a tropical city. Case Studies in Thermal Engineering, 14 (April).

Bavaresco, M. V., \& Ghisi, E. (2018). Influence of user interaction with internal blinds on the energy efficiency of office buildings. Energy and Buildings, 166, 538-549.

Chua, K. J., Chou, S. K., Yang, W. M., \& Yan, J. (2013). Achieving better energy-efficient air conditioning - A review of technologies and strategies. Applied Energy, 104, 87-104.

Gonçalves, J. C., Costa, J. J., \& Lopes, A. M. (2019). Analysis of the air infiltration through the doorway of a refrigerated room using different approaches. Applied Thermal Engineering.

Harkouss, F., Fardoun, F., and Biwole, PH. (2018), Passive design optimization of low energy buildings in different climates. Energy. 165, 591-613.

Indonesian Ministry of Energy and Mineral Resources. (2019). Indonesia 2050 Pathway Calculator Panduan Pengguna Untuk Sektor Rumah Tangga. Retrieved 2019, from http://calculator2050.esdm.go.id/assets/mini_paper/energy/i $\mathrm{d} /$ Panduan\%20Pengguna\%20untuk\%20Sektor \%20Rumah\%20Tangga.pdf

International Energy Agency. (2018). Key World Energy Statistics.

Jesha, T. A., \& Iqbal, M. T. (2015). Thermal simulation and energy consumption analysis of two houses in St. John's, Newfoundland. Procedia Engineering, 105, 607-612.
Jim, C. Y. (2014). Air-conditioning energy consumption due to green roofs with different building thermal insulation. Applied Energy, 128, 49-59.

Koroneos, C., \& Kottas, G. (2007). Energy consumption modeling analysis and environmental impact assessment of model house in Thessaloniki-Greece. Building and Environment, 42(1), 122-138.

Mechanical Engineering. (2017). Retrieved from https://www.mechlectures.com/tag/componentsof-cooling-load/

Praznik, M., Butala, V., \& Zbašnik Senegačnik, M. (2013). Simplified evaluation method for energy efficiency in single-family houses using key quality parameters. Energy and Buildings.

Shabunko, V., Lim, C. M., \& Mathew, S. (2018). Energy \& Buildings EnergyPlus models for the benchmarking of residential buildings in Brunei Darussalam. Energy \& Buildings, 169, 507-516.

Shi, Y., \& Li, X. (2018). A study on variation laws of infiltration rate with mechanical ventilation rate in a room. Building and Environment.

Wang, W., Rivard, H., \& Zmeureanu, R. (2006). Floor shape optimisation for green building design. Advanced Engineering Informatics.

Wong, N. H., \& Li, S. (2007). A study of the effectiveness of passive climate control in naturally ventilated residential buildings in Singapore. Building and Environment, 42(3), 1395-1405.

Yu, C., Du, J., \& Pan, W. (2019). Improving accuracy in building energy simulation via evaluating occupant behaviors: a case study in Hong Kong. Energy and Buildings, 19.

Yun, G. Y., \& Steemers, K. (2011). Behavioural, physical and socio-economic factors in household cooling energy consumption. Applied Energy, 88, 2191-2200. 